\title{
A Letter to My Muslim Readers
}

Something's wrong. Something's very wrong. But you already knew that. Every Friday khutba, every lecture, every dinner discussion about the plight of Muslims today seems to center on this foundational truth of our modern existence: something's wrong. The evidence is clear to anyone who's looking; from feckless leaders to systematic disempowerment to regressive institutions, we regularly and readily acknowledge amongst ourselves that something is deeply wrong with the current state of the Muslim community.

It's true; something is indeed wrong, but that fact doesn't bother me much. If there's one thing we've learned from increased connectivity and globalization, it's that every community's got something wrong with it. No community is free from violent factions, corruption, misogyny, racism, homophobia, and any number of other vices that pervade corners of our community, and no community is safe from being manipulated for political and economic gain. These are the hallmarks of most every community today, and Muslims are no exception.

No, what bothers me is not so much the fact that something is wrong, but the reason that our religious leaders most often give for why something is wrong. Across different countries and contexts, I consistently hear the same diagnosis given for the problems plaguing the Muslim community: we are not practicing Islam properly, and we are not following Islamic law. If we were to follow Islamic 
law correctly, we are told, all of the community's problems would instantly disappear.

For over a generation, I've heard that line repeated by scholars and community leaders the world over, and I'm disheartened to see a new generation of scholars repeating it to a new generation of Muslims with no end in sight. One would think that our leaders, after decades of delivering the same line with no demonstrable results, would try a different approach. After all, repeating the same thing over and over again but expecting different results is, as the saying goes, the very definition of insanity.

I don't believe in the line that our religious leaders constantly repeat to us-that we, the Muslim community, are the cause of all our problems because we are deficient believers with a substandard relationship to Islamic law. Our Prophet taught us to always give the community the benefit of the doubt and to put our trust in its collective wisdom, assuring us that "my community will not agree upon error." I believe that our community is always bent toward justice and that when we make our collective voices heard, we cannot be wrong. I believe this in all matters, including Islamic law. If our religious leaders have a problem with the Muslim majority's relationship with Islamic law, then the problem does not lie with us but with them.

We are taught to side with the community whenever we can and to have a healthy skepticism of institutionalized religious leadership. As a community, we do not recognize any official clerical hierarchy, and therefore no one person can officially say what is or is not Islamic law. That means that the entire community collectively owns Islamic law and that each one of us, as community members, has equal ownership rights. That is part of the beauty of our tradition; we all own the law together, no one can judge another's religious practice, and you never really know whose interpretation of the law is objectively right. This is a tradition of which we should be proud; it models a kind of radical egalitarianism in which all hu- 
mans have equal standing and in which legal pluralism is a central feature.

This is perhaps the defining aspect of the Islamic tradition, yet it often goes unmentioned by our religious leaders. That is because our leaders are, by and large, invested in giving the impression that they alone have exclusive knowledge of Islamic law. Many of them have made it their business to make you feel unworthy, unentitled, and unqualified to weigh in on Islamic law, regardless of whether you have engaged in careful textual study or not. Instead, they say that you ought to listen to their opinions without question. Many religious leaders-especially those who are also legal scholars-would have you believe that you must obey them in all things and that questioning them is tantamount to heresy, apostasy, and treason.

This authoritarian approach to Islamic law, built on shaming the community into compliance, violates the Islamic spirit and, perhaps more importantly, hides the fact that Muslim legal scholars, even those who are well-known, do not represent the will and wisdom of the community. Numerous studies and surveys have demonstrated a significant divide between Islamic legal scholars and the larger Muslim community that they claim to represent, and poll numbers suggest that most Muslims neither attend mosques nor listen to, or even respect, the opinions of legal scholars.

Having spent years studying in seminaries around the world, I have experienced firsthand the disconnect between legal scholars and the rest of the community. Seminaries tend to function like safe havens from the chaos of the modern world, and Islamic law can be discussed inside a seminary without reference to social and political realities. The result is that seminaries can become a parallel universe. People tend to think differently in seminaries and to hold beliefs that make little sense outside of them. They even speak in a particular dialect, one that uses lots of old-fashioned words and turns of phrase.

The scholars in these seminaries are demonstrably out of sync 
with the broader Muslim community, often clinging to outmoded ideas like gold-standard economics and Aristotelian physics. I've found myself in arguments with seminarians about gravitational pull, the existence of birth-control pills, and whether schizophrenia is caused by jinn possession. More importantly, I've seen the profound disconnect between the worldviews of most Islamic legal scholars and the majority of Muslims on foundational religious, social, and political issues. This disconnect is not so much because legal scholars reject the views of the Muslim community as that they don't even know about them to begin with.

I remember a seminary class on tax law, taught in Classical Arabic, in which our American-born, Pakistani-educated teacher read aloud from a thirteenth-century text about the different tax levies assessed on various types of jewelry: bangles, tiaras, anklets, earrings, broaches, necklaces, and much, much more. The student body was entirely male, as is the case with most seminaries, and this particular tax class was, from our perspective, entirely pointless. We didn't own any jewelry ourselves, but even if we had, we would have paid our taxes based on state law, not on the thirteenth-century text we were studying. At one point, the teacher looked up from his book and saw that we had clearly checked out. He hit the table and said, "You need to pay attention! You have to know this so that you can teach it to your mothers and sisters and wives."

One student, fighting boredom, chimed in, "Or to a guy with an earring."

Our American-born teacher, in genuine disbelief, asked, "Why would a guy have an earring?"

While legal scholars have been studying in seminaries and parsing medieval texts, the Muslim community has moved on. Whereas legal scholars continue to argue about whether men and women can work in the same space, Muslim-majority states have created quotas to ensure female representation in their parliaments. As legal scholars debate whether democracy is "Islamic," most Muslims have cho- 
sen democratic rule for themselves and report that they believe democracy to be the ideal system of governance.

Some of our religious leaders have embraced the community's changing beliefs and practices, but many more have not. Most have responded by saying that the Muslim community is doing things wrong, that it is on a dangerous path, and that Muslims must repent and change their ways if they hope to attain salvation. But if we believe in the collective wisdom of the community, then it is not the community that is wrong but the disconnected religious scholars who oppose the community. If the community cannot agree upon error, then, to determine correct practice, we as community members have to make clear what we actually agree upon rather than rely on a small group of people to tell us what we ought to agree upon.

That will require us to speak back to the religious elite and to ourselves articulate Islamic laws that better represent our beliefs and aspirations. To do that, we will first have to become literate in Islamic law and become comfortable speaking its language. That will require familiarizing ourselves with the foundations of Islamic legal thought and becoming skilled in an ancient Islamic legal practice, called in this book "hacking."

Hacking is a modern term that describes the process of using existing tools to make something work better or more efficiently. Whenever someone comes up with a new use for an existing product or combines previously unrelated things to solve a problem, we call that a hack. Essentially, hacks are ways to solve problems using no new tools. Businesses now encourage hacking cultures, and institutions run hack-a-thons that bring together teams of unrelated individuals to solve thorny problems. Many universities, including my own, teach courses on ethical hacking to teach students how to come up with ingenious solutions to social problems without causing unintended harm.

Hacking is about working within a system, using its existing tools to make it work better without bringing the whole thing down. 
I use the term hacking in that sense, and in that sense, hacking is a time-honored Islamic legal tradition. From the earliest times, Muslim scholars wrote legal codes that they claimed reflected values and ideals sanctioned by the community. Whenever the community's values and ideals shifted, scholars would adjust laws, not by rewriting legal codes from scratch but by hacking existing codes so that they changed specific, targeted groups of laws while leaving the underlying legal structure intact. They did this to, for example, abolish slavery, embrace religious pluralism, and develop "sharia-compliant" financial vehicles, among many other things. Each time, rather than reject or replace old laws, Muslim legal scholars hacked them, making them work differently and better in new contexts. As you will see in this book, almost any law can be hacked in this way to better reflect the evolving collective wisdom of the community.

Muslims have been hacking Islamic law for centuries using highly intricate and sophisticated methods. These methods are tried and true and can be learned by anyone with the requisite interest and dedication. That is fortunate, because we need more Muslims to engage in hacking if Islamic law today is to reflect the beliefs of the larger Muslim community. Islamic law has divine sanction only when it reflects the beliefs of the community, and to get to that point, we need community members to express their beliefs about Islamic law.

Hearteningly, Muslims around the world - in Nigeria and Indonesia and Iran and India and North America-are using newfound modes of connectivity to express their deeply held beliefs in the language of Islamic law. Millions of Muslims are now hacking Islamic law free from the watchful eye of the state and the religious establishment. Their hacks challenge common assumptions about Islam and Muslims promoted by powerful religious and political actors. They openly and unreservedly embrace values like human rights, gender egalitarianism, and religious liberty—values that polls suggest most Muslims today support. Importantly, these modern hacks 
are carefully argued and thoroughly researched, drawing on over a thousand years of Islamic thought, and are expressed in a language that respects an ancient Islamic legal tradition without compromising contemporary ideals.

More Muslims need to take part in hacking to express the collective will of the community and to put pressure on our leaders to take our ideas seriously, fully engage with them, and ultimately adopt them as the truest expressions of Islamic law. This book is designed to help you do that. It will introduce you to the hacking conversation so that you too can express yourself as a community member using the language of Islamic law. Your voice will help us get one step closer to having Islamic law reflect the beliefs of the Muslim community and serve as a forward-looking force for good in this world.

Your voice is also your right; as members of a radically egalitarian community, each one of us has just as much right to Islamic law as anyone else. And in this day and age, in which our thoughts can be shared and amplified without going through official channels, it is our responsibility to make our voices heard and our views known. The fact is, something is wrong. But we are not the problem. We are the solution. 
This page intentionally left blank 
SHARIA COMPLIANT 
This page intentionally left blank 